\title{
Can Romania offer a sustainable environment for the FDI inflows?
}

\author{
Associate Professor, Laura DIACONU (MAXIM) ${ }^{1}, \mathrm{PhD}$.
}

\begin{abstract}
It is well known that the foreign direct investments (FDI) represent a key factor for the economic growth of the developing states. Despite Romania's efforts of creating a favourable environment for the foreign investors, the global economic and financial crisis has considerably diminished its attractiveness for the multinational companies. Considering these aspects, the purposes of the present paper are to identify the factors that currently attract the foreign investors in Romania and to analyse if they can be valued on long term. In order to reach these goals, several research methods were used. First of all, after analysing the specialised literature, we have conducted in-depth interviews on managers and experts from 14 multinational companies that are present in Romania, in order to identify the determinants of the FDI. Secondly, to see if these factors might represent long term advantages, we have we analysed the secondary data offered by various statistical yearbooks, reports and by different empirical investigations. The relevance of this study results from the fact that the conclusions may offer valuable information for the Romanian policy makers to create a favourable environment for the FDI inflows, on long term.
\end{abstract}

Keywords: FDI determinants, Romania, buman capital, low production costs, long term favourable environment

\section{Introduction}

The financial capital is an essential factor for the economic growth and development of a country, which is influencing and is also influenced by other determinants, such as human capital and technology. The new theories of growth, which highlight the impact of the technological progress on the long-term growth rates, state that the FDI should be considered one of the key factors for enhancing the economic growth (Ozturk and Kalyoncu, 2007). Unlike the developed countries which, according to the Austrian economic theory, already have this capital because they have accumulated it through savings, the developing states are lacking it. In their case, it is considered that, from all the private and public financing sources, the best way to obtain the capital is to attract the foreign investors, since they directly control their activity and are interested in making profit. Actually, it can be argued that the foreign direct investments (FDI) are a vehicle through which new ideas, techniques, technologies, skills and organizational practices are transferred to the receiving country.

After the communism period, Romania, as the other developing countries from the Central and Eastern Europe, has focused on attracting the foreign investors. However, unlike in other former communist states, the Romania's transition period was very long and difficult. This is one of the reasons why, until 2000, the number and the amount of 
the FDI inflows was relatively low. At the beginning of the XXIst century, the number of the attracted foreign investors has increased, together with the value of their investments. This positive trend was more visible especially after 2004, when various EU pre-adhesion measures were implemented.

Starting from the moment of the EU adhesion, Romania has experienced a significant increase in the FDI inflows, reaching the historical maximum level in 2008. However, the consequences of the global economic and financial downturn have been influencing Romania since 2009. Actually, in this year the number of the attracted foreign investments has almost halved, compared to 2008. Since then, despite some occasional increases, Romania could not regain a sustainable positive trend of the FDI inflows.

Taking into consideration all these aspects, in the following parts of the paper we will identify the factors that are currently attracting the foreign investors in Romania and we will analyse if they might represent long term advantages.

The relevance of this study results from the fact that the conclusions may offer valuable information for the Romanian policy makers to create a favourable environment for the FDI inflows, on long term.

\section{Objectives and research methodology}

The purposes of the present paper are to identify the factors that currently attract the foreign investors in Romania and to analyse if they can be valued on long term. In order to reach these goals, several research methods were used.

Firstly, we have analysed the specialized literature, which helped us shape the theoretical framework of the factors that are attracting the foreign investors in Romania. Secondly, we have conducted in-depth interviews on managers and experts from 14 multinational companies, partly/entirely financed with foreign capital, which are present in Romania. The initial sample included 20 companies, but the managers/experts from 6 of them refused to take part to our interview. Most of the companies included in the sample are from the services' sector and some others from industry. According to their size, 7 of the selected firms have between 10 and 49 employees, the rest of them having 50-149 people. The firms were selected from five out of the eight development regions of Romania, respectively from the regions: North-East, South-East, South, Bucharest-Ilfov and North-West.

In order to see if all these factors, identified through the in-depth interviews, might represent long term advantages for Romania, we have we analysed the secondary data offered by the specialized literature. These secondary sources included various statistical yearbooks and reports, as well as different empirical investigations. Considering the fact that the number and the amount of the FDI attracted by Romania before 2000 were reduced, the data was collected for the period of time between 2000 and 2015/2016.

\section{The determinants of the FDI's inflows in Romania}

\subsection{Theoretical background}

When explaining the FDI determinants, the specialized literature provides both economic theories that present the investing decision of the multinational companies and the econometric analysis of the impact of some local factors on FDI. One of the most 
cited theories when analysing the determinants of the foreign investments belongs to Dunning. Based on the reasons of the investments, Dunning (1993) presents three main types of FDI: market-seeking ones - whose aim is to expand the activity on other local and regional markets, resource-seeking investors - when firms invest abroad to obtain resources not available in the home country and efficiency-seeking firms - when companies can gain from the common governance of the geographically dispersed activities, in the presence of economies of scale and scope.

Taking into consideration the results of some econometric studies, Artige and Nicolini (2005) notice that the market size, measured with the help of GDP or GDP per capita, is the major FDI determinant. An explanation of this factor is offered by Charkrabarti (2001) who considers that a large market will offer the opportunity of the efficient utilization of resources and the exploitation of the economies of scale. However, Charkrabarti (2001) states that not only the market dimensions are important in attracting the FDI, but also the country's level of openness, measured through the ratio of exports plus imports to GDP. Previous studies, such as that conducted by Kravis and Lipsey (1982) or Edwards (1990), have also found a strong positive impact of openness level on FDI.

The low cost of the labor force has also been mentioned as a major FDI determinant factor, especially in the case of the South-Eastern Asian countries, as it results from a study conducted by Shi (2001). The low labor cost also seems to be an important factor in attracting the foreign investors in the Eastern European states, especially since here the individuals are highly trained (Bartlett, 2007).

In the economic literature of the XXIst century, another important determinant of the FDI has gained ground: the human capital. As Reisen and Soto (2001) noticed, achieving a certain level of education became one of the main preconditions for a country, especially for a developing one, to attract and maintain the foreign investors, particularly the efficiency-seeking multinational companies.

However, the ability of people to gain proper skills and knowledge is more likely to develop in an environment governed by laws, where their rights are respected. Moreover, Blanton and Blanton (2007) argue that the state credibility decreases the political risk and the proper regulatory framework can enhance the ownership advantages.

To all these factors, some other additional reasons that enhance the FDI inflows can be mentioned such as the political implication in creating the "special economic zones" (Chidlow, Salciuviene and Young, 2009), which offer fiscal facilities to the multinational companies, or the growth rate of a country (Resmini, 2000), being argued that rapidly growing economy provides relatively better opportunities for making profits.

Lall, Norman and Featherstone (2003) have grouped all these factors that attract the foreign investors in three major categories: "supply-side" ones - skilled labour, research and development or infrastructure, "demand-side" determinants - related to the host country economic and social variables, and "institutional factors" - with a significant impact on the two other groups.

A study published by Allen and Overy LLP in 2008 states that the major determinants of the FDI inflows in the Central and Eastern European countries belong to the following categories: low-cost of the real estate; low taxation and fiscal facilities to investors; 
availability of the European funds; availability, low-cost and highly skilled labour force, good infrastructure; geographical position and economic stability.

\subsection{Empirical evidences from Romania}

The importance of the FDI determinants mentioned by the specialized was tested on the case of Romania with the help of in-depth interviews conducted on managers and experts from 14 multinational firms, partly/entirely financed with foreign capital, which are present in Romania.

The results we have obtained indicate that most of the factors mentioned by the specialized literature are also present in the case of Romania. However, only four aspects were mentioned by all the respondents: the low costs of production (including wages), the availability of the labour force with adequate qualifications and skills and good knowledge of a foreign language, the economic freedom and the fiscal facilities. Taken into consideration the location of their company in Romania, we can notice that some of the investors from the North-West part of the country have also indicated the relatively good infrastructure, the market potential and the geographical proximity to the Central European states, as determinants of their investments. Meanwhile, the investors from the North-East part of Romania have said that the little competition from this region was another determinant for them. Some of the foreign companies located in the South, North-West and Bucharest-Ilfov regions have also indicated the availability of the subcontractors and suppliers. Two of the interviewed companies' representatives have also mentioned that their companies have taken the investment decision in Romania due to the relatively good institutional environment and macroeconomic stability, compared to other countries in which they have entered.

In order to assess the importance of the reasons of investing in Romania, the respondents were asked to give grades from 1 to 5 to all the mentioned aspects, where 5 represented 'very important reason' and 1 'least important reason'. Based on the obtained results, an average score was calculated for each indicated reason. The hierarchy and the scores of the four reasons indicated by all the 14 respondents can be seen in Table 1. It is noticeable that the first position is occupied by the low costs of production, followed, at a very short distance, by the highly skilled labour force. Considering this fact, we may assume that the companies which decide to invest in Romania are especially attracted by the low cost of the qualified labour force.

However, looking at the scores obtained by the four aspects, it is obvious that all of them are quite close, the distance between the first one and the fourth one being less than 0.8 points.

Table 1: The importance of the reasons of investing in Romania

\begin{tabular}{|l|l|l|}
\hline Position & Factor & Average score \\
\hline 1 & Low costs of production (including wages) & 4.36 \\
\hline 2 & $\begin{array}{l}\text { Availability of the labour force with adequate qualifications and } \\
\text { skills }\end{array}$ & 4.14 \\
\hline 3 & Fiscal facilities & 3.93 \\
\hline 4 & Economic freedom & 3.57 \\
\hline
\end{tabular}

Source: Own research 
Looking at the frequency of the other 7 reasons, indicated only by some of the respondents, we can notice that the market potential has mentioned by 7 of the companies' representatives, followed by the low competition ( 5 respondents) and by the geographical proximity to the Central European states (4 respondents).

Being asked to point out some aspects that might determine the multinational companies to diminish or even stop the activity developed in Romania, most of the respondents have indicated the corruption, the bureaucracy and the risks resulted from the political instability. Moreover, all the 14 respondents have mentioned the risk of increasing the production costs, especially wages, as a threat for their investment in Romania.

In order to see if these threats are likely to become real and whether the four main FDI determinants, mentioned by all the respondents, might represent long term advantages for Romania, we have we analysed the secondary data offered by the specialized literature.

\section{FDI determinants - long term advantages for Romania?}

A first analysed aspect was the risk of increasing the production costs. According to the analysts, developing countries cannot infinitely benefit from the low production costs' advantage. Once they are passing from the developing to the developed stage, all the costs, and consequently the prices, will increase. This aspect has been largely debated on the case of China, Kay (2008) arguing that even if the level of the wages is still low compared to other developing countries, the labour costs have significantly increased since 2004 especially in those regions that have fastest developed.

Analysing the evolution of the minimum gross wage in Romania, we can notice that between January 2000 and May 2016 it has increased of approximately 28 times, from 45 lei to 1250 lei (see Figure 1).

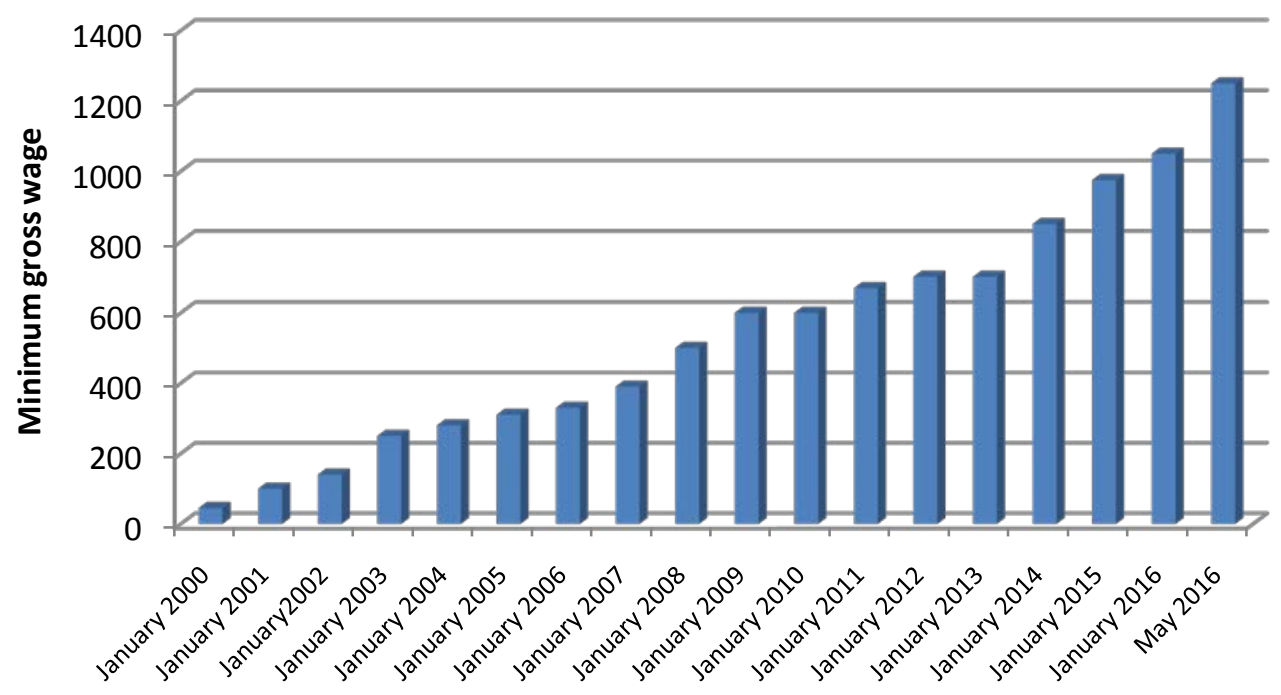

Figure 1: The evolution of the minimum gross wage in Romania

Source: Own adaptation of data from Monitorul Oficial, 1999-2015

(C) 2016 The Author. Journal Compilation ～(C) 2016 European Center of Sustainable Development. 
Looking at the data from Figure 1, we can see that there are 2 periods in which the minimum gross wage had a significant positive trend: January 2000 - January 2009 and from the beginning of 2013 and up to now. During the period January 2009 and January 2013 the minimum gross wage did not changed too much, registering only very small increases between 2010 and 2012.

This evolution of the minimum gross wage can be correlated to the economic situation of Romania. As we can see from Figure 2, between 2000 and 2008 Romania registered a continuous growth. Actually, this was the longest period of growth during the last decades. Starting with 2009 and until 2013, the consequences of the global crisis were strongly felt in Romania. In 2009, Romania's GDP decreased with 7.1\% compared to 2008, the downward trend also continuing in 2010. In 2011 and 2012, only small increases in GDP were registered, less than $1 \%$. However, the ascending trend was more visible starting with 2013.

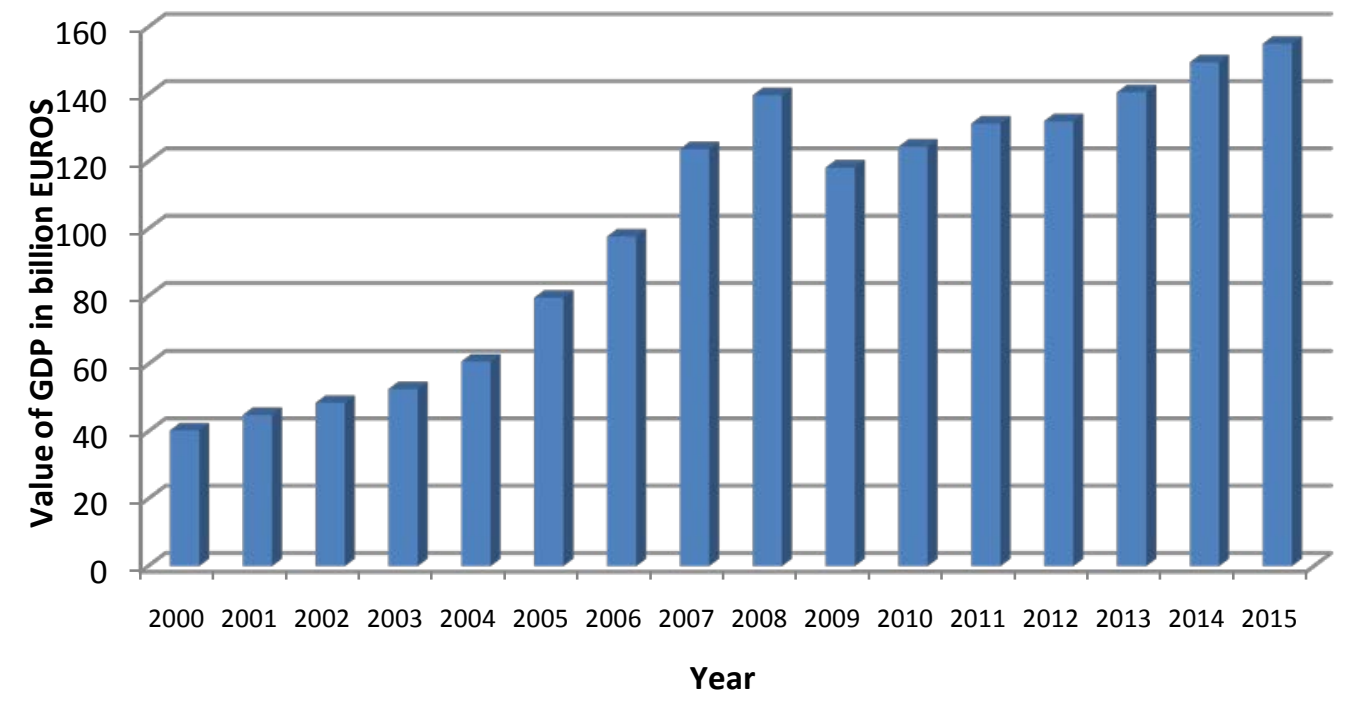

Figure 2: The evolution of the GDP in Romania (in billion Euros)

Source: Own adaptation of data from National Institute of Statistics, 2001-2016

According to the estimations made by the National Institute of Statistics (2015) for the period 2016-2018, it is very likely that Romania's GDP continues the positive trend started in 2013, with an average annual increase of around 3\%. In this context, it is assumed that the wages will also increase.

From the point of view of the availability of the human capital stock on long term, World Economic Forum (2015) shows that Romania has increased its performances, compared to previous years. In a ranking regarding the Human Capital Index, in 2013 Romania was placed on the 69th position, out of 122 states (World Economic Forum, 2013). In the same raking, in 2015 the country ascended 30 places, obtaining an overall Index of 73.94 (World Economic Forum, 2015). This positive evolution was mainly due 
to the improvements registered by Romania in the aspects included in the first and second pillar of the Human Capital Index: 'Education' and 'Health and Wellness'.

However, from the point of view of the Human Capital Index, even if Romania is placed before Greece or Spain, the country is on the last positions among the Central and Eastern European states, only Bulgaria being after it.

Regarding the economic freedom, Figure 3 presents the evolution of the Index of Economic Freedom in Romania between 2000 and 2016, based on the data offered by the Heritage Foundation for this period. We can see from Figure 3 that, since 2004 and up to 2015, the Index of the Economic Freedom has had a positive trend, the highest increases being registered before Romania's EU adhesion. However, in 2016 the country lost 1 percentage point compared to previous year, the Heritage Foundation (2106) including Romania, from the point of view of the economic freedom status in the category 'moderately free'. Compared to the world average (60.7), Romania's Index is superior, but it has a lower value in comparison with the regional average (66.9). This suggests that Romania has less economic freedom than other states from the Central and Eastern Europe.

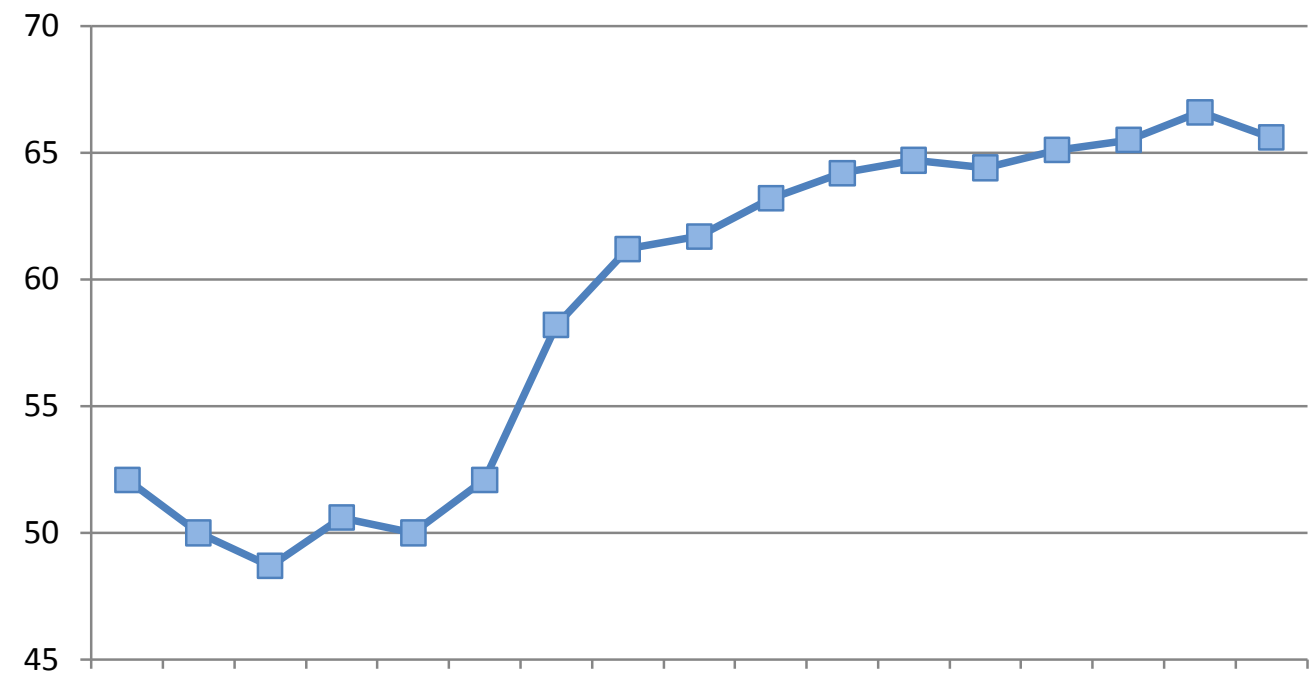

20002001200220032004200520062007200820092010201120122013201420152016

Figure 3: The Evolution of the Economic Freedom Index in Romania

Source: Own adaptation of data from Heritage Foundation, 2000-2016

Analysing the elements included in the pillars of the Index of Economic Freedom, we can notice that Romania has gained noticeable success in liberalising the trade and the monetary market, due to the fact that it continues to place a high priority on restoring the fiscal sustainability and on improving competitiveness by easing and rationalizing the regulatory burden. However, the major concerns are related to the labour freedom, to the fact that the institutional shortcomings make difficult to enhance respect for the rule of law and to the high levels of corruption, exacerbated by a relatively inefficient judicial system. 


\section{Conclusions}

According to the specialized literature, among the most important FDI determinants are the market size and its growth potential, the country's level of openness, the macroeconomic and political stability, the geographical position, the low cost of the labor force and the fiscal facilities offered by the host state. Apart from these traditional aspects, especially in the economic literature of the XXIst century some other important factors that attract the foreign investors have been revealed: the human capital and the rule of law.

The results we have obtained after conducting the in-depth interviews on managers and experts from 14 multinational firms indicate that most of the factors mentioned by the specialized literature are also present in the case of Romania. However, only four aspects were mentioned by all the respondents: the low costs of production (including wages), the availability of the labour force with adequate qualifications and skills and good knowledge of a foreign language, the economic freedom and the fiscal facilities. Some other determinants, indicated only by some of the respondents, regarded the relatively good infrastructure (in the North-Western part of Romania), the market potential, the geographical proximity to the Central European states, the low competition (from the North-East region of the country), the availability of the subcontractors and suppliers and the relatively good institutional environment and macroeconomic stability, compared to their previous experiences in other states.

The major aspects they consider that might be threats for their future investment in Romania are the risk of increasing the production costs, especially wages, the corruption, the bureaucracy and the risks resulted from the political instability.

Looking at the statistics, we can see that the minimum gross average has increased in Romania since 2000 and up to now of approximately 28 times, in the context of the economic growth of the country. The specialists assume that, in the next years, the country will continue to register economic growth and, consequently, the wages will probably increase. Taken into consideration the fact that the low cost of production, including wages, was the main factor mentioned by our interviewed companies' representatives as a determinant for their investment in Romania, it is likely that they might search for other economies to which to relocate their activities. However, this will occur only if the other major advantages found by them in Romania will disappear, on long term.

Even if Romania has improved the Human Capital Index, the country is placed on the last positions among the Central and Eastern European states, being followed only by Bulgaria. In this context, we may assume that the multinational companies might be, in future, more attracted by other low cost markets from the region, which can offer them a superior level of human capital.

Moreover, considering the fact that Romania's Index of Economic Freedom has a value situated below the regional average in 2016, it is possible that the foreign companies redirect their investments to the neighbouring countries, if this situation does not improve in future.

To all these shortcomings, it also adds the fact that Romania confronts with various institutional problems, which make difficult to enhance respect for the rule of law, and 
with high levels of corruption. All these aspects should raise an alarm for the policy makers since they might negatively influence the future foreign investments in Romania.

\section{Acknowledgement}

This work was funded by "Alexandru Ioan Cuza" University of Iasi, through the project no. 20/03.12.2015, in the competition Grants for young researchers of $U A I C$.

\section{References}

Allen \& Overy LLP. (2008). Foreign Direct Investment in Central and Eastern Europe. Retrieved from http://www.allenovery.com/AOWeb/binaries/27644.PDF

Artige, L. \& Nicolini, R. (2005). Evidence on the Determinants of Foreign Direct Investment: The Case of Three European Regions. Retrieved from http://pareto.uab.es/wp/2005/65505.pdf

Bartlett, D. (2007). Eastern Europe Offers Low-Cost, High-Growth Opportunities. RSM McGladery Report. Retrieved from http://www.rsmmcgladrey.com/RSM-Resources/Articles/Advantage/BusinessClimate/Eastern-Europe-offers-low-cost--high-growth-opportunities/

Blanton, S.L. \& Blanton, R.G. (2007). What Attracts Foreign Investors? An Examination of Human Rights and Foreign Direct Investment. The Journal of Politics, 69(1), 143-155.

Charkrabarti, A. (2001). The Determinants of Foreign Direct Investment: Sensitivity Analyses of CrossCountry Regressions. Kyklos, 54(1), 89-114.

Chidlow, A., Salciuviene, L. \& Young, S. (2009). Regional determinants of inward FDI distribution in Poland. International Business Review, 18(2), 119-133. Doi: 10.1016/j.ibusrev.2009.02.004.

Dunning, J. H. (1993). Multinational Enterprises and the Global Economy. Harlow, Essex: Addison Wesley publishing Co.

Edwards, S. (1990). Capital Flows, Foreign Direct Investment and Debt - Equity Swaps in Developing Countries. NBER Working Paper No. 3497. Retrieved from http://www.nber.org/papers/w3497.pdf

Heritage Foundation. (2000-2016). Index of Economic Freedom - Romania. Retrieved from http://www.heritage.org/index/explore?view=by-region-country-year

Kai, C. (2008). The End of China's Low-Cost Labor?. Special Report, 357, 13-14.

Kravis, I. B. \& Lipsey, R. E. (1982). Location of Overseas Production and Production for Exports by U.S. Multinational Firms. Journal of International Economics, 12, 201-223.

Lall, P., Norman, D. W. \& Featherstone, A. M. (2003). Determinants of US Direct Foreign Investment in the Caribbean. Applied Economics, 35(13), 1485-1496.

Monitorul Oficial. (1999-2015). Government Decision to establish the minimum gross salary per country guaranteed in payment. Retrieved from http://www.monitoruloficial.ro/

National Institute of Statistics. (2001-2016). Gross Domestic Product. Retrieved from http://www.insse.ro/cms/en/content/gross-domestic-product

Ozturk, I. \& Kalyoncu, H. (2007). Foreign Direct Investment and Growth: An Empiricial Investigation Based on Cross-Country Comparison. Economia Internazionale, 60(1), 75-82.

Reisen, H. \& Soto, M. (2001). Which Types of Capital Inflows Foster Developing-Country Growth? International Finance, 4(1), 1-14. Doi: 10.1111/1468-2362.00063.

Resmini, L. (2000). The Determinants of Foreign Direct Investment in the CEECs. Economics of Transition, 8 (3), 665-689.

Shi, Y. (2001). Technological Capabilities and International Production Strategy of Firms: The Case of Foreign Direct Investment in China. Journal of World Business, 36(2), 184-204.

World Economic Forum. (2013). The Human Capital Report. Retrieved from http://www3.weforum.org/docs/WEF_HumanCapitalReport 2013.pdf

World Economic Forum. (2015). The Human Capital Report. Retrieved from http://www3.weforum.org/docs/WEF Human Capital Report 2015.pdf 